Pro-Fil 22 (2) 2021: 45-55

https://doi.org/10.5817/pf21-2-2310

\title{
GOD, WORSHIP, AND FREEDOM
}

\author{
DAVOR PEĆNJAK \\ Institute of Philosophy, Zagreb, Croatia, davor@ifzg.hr \\ TVRTKO JOLIĆ \\ Institute of Philosophy, Zagreb, Croatia, tjolic@ifzg.hr \\ RESEARCH PAPER • SUBMITTED: 15/4/2021 • ACCEPTED: 11/11/2021

\begin{abstract}
In this article, the authors give an answer to the question of whether God would be worthy of worship had He created (or even permitted) a world where no human action was freely done. Presupposing God's omnibenevolence in applying the doctrine of no responsibility for actions not freely done, we consider two possible answers to the question of why God would create such a deterministic world. Whichever of these answers proved to be true, we conclude that God would be worthy of worship because He would provide the best outcome for everyone.
\end{abstract}

Keywords: determinism; forknowledge; free will; incompatibilism; responsibility

\section{Introduction}

We would like to examine the following question, which seems interesting in itself, namely, whether God would be worthy of worship had He created (or even permitted) a world in which human beings do not enjoy freedom of the will and no human action is freely done.

Namely, we would like to examine whether there is a possible scenario in which God would be worthy of worship even if the world $\mathrm{He}$ created were deterministic (in one way or another) or the world were such that theological fatalism was the case. We do not actually know whether our world is deterministic or whether theological fatalism is the case, so we would like to propose that there could be a scenario in which God is worthy of worship even though the world is deterministic or theological fatalism is the case. Our aim is not to examine another possibility - namely, that everyone could be saved - this outcome is only a "means" in our argument for showing that God is worthy of worship even under the circumstances in which He created a fully deterministic world. ${ }^{1}$ We also do not go into the

\footnotetext{
${ }^{1}$ There are proposals how everybody could be saved - for example, Kronen and Reitan (2011) argue that God could grant infinite time to human beings in order that human beings eventually stop sinning, and after no one sins anymore, everybody could be saved and go to Heaven.
} 
defence of determinism, libertarianism, theological compatibilism or theological incompatibilism regarding God and freedom of His created (human) beings. ${ }^{2}$

Traditional Christian theism claims that human beings are created by God and that they posses freedom of the will and freedom of action in the libertarian sense. ${ }^{3}$ Somewhat simplified, because we shall not go into the free will debate details, which are not so important here, libertarian sense of freedom means that an agent freely did $\mathrm{Y}$ at $\mathrm{t}$, if he can do otherwise, at $t$, than what he in fact did, under the same (antecedent) circumstances. ${ }^{4}$ Freedom of the will and freedom of action are considered as great gifts to humankind by God, and, apart from very existence, one of the great values by itself that human beings posses (as God-given ability); and, if we really do posess these freedoms, and we believe that this is indeed the case, they certainly are great values. But, still, it could have been that human beings are such that they do not posess freedom of the will and freedom of action, or either. It is not hard to imagine or conceptualize that God might create a world in which no human action and no individual will is free.

Traditional theism also grants that God is a being that possesses divine attributes such as omnibenevolence, omniscience, omnipotence, eternity, necessary existence. These attributes are among the essential attributes of God. God may also have attributes that are inessential to Him. But it is impossible that a being who is God lacks one or some of the essential attributes. Of course, how exactly we analyse these attributes and what exact meaning the predicates that express them are to be given is a matter of detailed controversies. But, we do not aim to settle these diputes here. As we stated already at the beginning, we would like to examine just the question whether God would be worthy of worship if it is the case that no human decision and action is freely done.

The question is why we would like to do that? Well, usually it goes without saying that God is such a being that deserves to be worshipped. What does that mean? We shall think about

\footnotetext{
${ }^{2}$ See Smith (1997) and Pruss (2008) for a debate on whether God can create compatibilistically free agents who would not sin at all. Smith thinks that God can do it, while Pruss disagrees. By the way, we do not think that compatibilism is in any way a viable theory regarding the freewill problem, and since a defense of any position in the free will debate is not our concern here, we shall not dwell into this debate deeply here. For an interesting theory that God, as morally perfect being who loves His creatures, should grant His rational acting beings with libertarian will, i.e., that this love for creatures entails libertarianism, see van Inwagen (2006, 8690).

3 There are some thinkers, notably van Inwagen $(1983,1989)$, who think that libertarian freedom is seldom exercised, for example only in some complex situations with moral content and significance. However, we think that, if the metaphysical structure of the world is such that it enables libertarian freedom, then we can have libertarian freedom in most if not in all situations of deciding and action, even regardless of the habits we develop in our behavior. We shall not dwell into a defense of this position because it is not important for our theses here, but we think that "libertarian metaphysical structure" of the world, if one obtains, is such that it is inherent in the structure of the agent and inherent in the process of deciding and action whatever this process is - choosing water over whisky or some complex moral deciding - the structure of the world does not differentiate between specific contents of decisions and actions. Moreover, though they may be controversial, there are certain experimental results that could point that we have libertarian freedom at the very simple level of decisions and actions - see Schultze-Kraft et al. (2016).

4. There are, mainly, three kinds of libertarianism: agent-causal (O'Connor 2000), non-causal (Goetz 2008, Ginet 1990), and event-causal (Kane 1996). Since, for the purposes of our article, it is not necessary to argue for some specific variant of libertarianism, we shall not attempt to do this; just for the curiosity of potential readers, our inclinations are set in the above order. As it will be obvious also, we shall not attempt to try to solve the problem of God's foreknowledge and human freedom, because this is also not required by what we would like to say in this text. See, for example Warfield (1997) and Huemer (2021, chapter 10) for persuasive arguments that God's foreknowledge is compatible with human freedom.
} 
worship in terms of great or enormous respect ${ }^{5}$ and that a certain being is to be worshipped in virtue of qualities and attributes that it possesses. It would mean that some object of worshipping is such an entity that has certain properties, and/or certain functions and/or has done (or continually does) notable deeds, especially deeds for others.

\section{What does it mean to be worthy of worship?}

We can say the following: that some entity is worthy of worship consists in that entity's having some properties that deserve great or enormous respect and/or having some functions which deserve great or enormous respect, and/or having done (or continually doing) deeds that deserve to be greatly or enormously respected (for deeds we may say that they deserve great merit). We here rely on Swinburne's account about the meaning of who is 'worthy of worship' (Swinburne 1993, chapter 15). If God is the creator and sustainer of the universe, these facts surely deserve merit and great respect, so the being who is "de facto and de iure lord of all things" (Swinburne 1993, 293), in virtue of this "lordship" over its creation, is worthy of worship. As we said above, God is traditionally endowed by the attributes which are predicated in superlatives: He is omnipotent, omniscient, wholly good, eternal - the being who has these attributes should be enormously respected and so this enormous respect is, in fact, worthines of worshiping that being. That being is worthy of worship in virtue of being as such - as having these superlative attributes and, moreover, these superlative attributes are used to benefit others, namely to benefit some of His creations. We even pay respect to people who have profound general knowledge, or are knowledgeable in some special area, who can do many good deeds, who sincerely care for others, etc. So it is certain that being who has these qualities in superlative quantities is to be greatly respected and so to be worshipped. There are even more important reasons why God is worthy of worship. These reasons are tightly connected with us and our existence as human beings. They spring from several considerations. He created us; moreover, He created us in His image; He provides for us in this world during our lives; He cares for humankind in general and for each and every single human being; He gives us an opportunity for eternal life in Heaven, He grants us many good things in our life (to grow in goodness, knowledge to enjoy nature, each other's company etc.).

We also assume that God did all this freely, e.g., that He Himself acted by His free will in the libertarian sense; which, it seems, confers even more worthiness of worship on Him. It is so because we pay respect for deeds that are done freely and which are such that they haven't had to be done; that there was no moral or any other kind of obligation for doing them; and that they were not necessitated by anything. They were free and gratuitous and fully benevolent to the creatures created. For these reasons God is certainly worthy of worship. One more thing for which it seems that He is (perhaps most of all) worthy of worship is that (perhaps in his image) human beings are created as such that they themselves have free will in the libertarian sense, e. g., that in most, if not all, situations, human beings can do otherwise than they have in fact done.This would make us co-creators of, at least, some events in our universe, which would be, we assume, a great gift, perhaps the greatest, beside our bare existence, for us, human beings. So freedom of the will, besides our very existence, seems as one of the gretaest values for which we have to respect God and have to worship Him on that account.

But what if there is or there would be no free will in our or in some possible world? Would God be still worthy of worship? It seems that the answer is no. It seems that, in this case, we

\footnotetext{
${ }^{5}$ For the notion of "respect" see Dillon (2018).
} 
would be lacking one of the most precious gifts of God, in which we are perhaps closest creatures 'in His image', and that withdrawing to give human beings freedom of the will and freedom of the action, would be so severe a condition that that condition alone would be enough to entail that God then would not be worthy of worship.

\section{Freedom and non-freedom}

One problem which can confront traditional theistic claim that human beings are created such that they have libertarian freedom of the will is the problem of God's foreknowledge which springs from His omniscience. We also do not attempt to resolve that problem, and nothing we say here depends on a solution of 'freedom and foreknowledge' problem. However, we find here another locus of the potential problem for the claim of worthiness of worship. So, let's examine these matters.

God is essentially omniscient (among other essential divine attributes). On most versions of the analysis of that attribute, He knows everything that human beings will do in the future; so there is a problem whether God's foreknowledge is compatible with human freedom. It consists in the following: Since God is essentially omniscient, at a time t1, which is prior to time $\mathrm{t} 2, \mathrm{He}$ believes that Jones will do action $\mathrm{X}$ at $\mathrm{t} 2$. Were Jones able at $\mathrm{t} 2$ to do otherwise, namely not-X, then it would be in Jones's power to render false God's belief, and that would mean that God is not essentially omniscient. But God is essentially omniscient; if that being held a false belief, or even if it were possible for such a being to hold a false belief, then it would be in Jones's power to make that God is not in fact God, or to make that God in fact does not exist. Both of these claims are implausible. Or it would be in Jones's power at $\mathrm{t} 2$ to make that God did not hold a belief that He held at $\mathrm{t} 1$. But this is impossible because of the Principle of the Fixity of the Past: no one has the power at a later time so to act that the past would have been different from what it actually was. Therefore, human freedom is incompatible with God's foreknowledge, which derives from His being essentially omniscient. The conclusion would be that no human action is performed freely (in the sense of the human agent being able to do something other than he has in fact done). Those who defend this conclusion are incompatibilists regarding God's foreknowledge and human freedom (see Pike 1965, though he later changed his view on compatibilism, and Fischer 1983, 1985, 1994), whereas compatibilists are those who defend the view that we can have both God's foreknowledge and human freedom (see Zagzebski 1991, McCord Adams 1967, Warfield 1997, Hasker 1989, and Plantinga 1974). An interesting view is set forth by Hoffman and Rosenkrantz who analyze the attribute of omniscience as 'maximal possible knowledge' which does not require God to know what human beings will do freely in the future (Hoffman and Rosenkrantz 2002, ch. 6). According to them, God actually cannot know this, but $\mathrm{He}$ is nonetheless omniscient in the sense of possessing maximal knowledge which cannot be met in quantity and quality by any other being.

\section{The origin of question}

The question - whether God would be worthy of worship had He created a world in which no human action is freely done - springed in an exchange between John Martin Fischer and Nelson Pike on the problem of free will and foreknowledge, but only as an ephemeral side-issue (see Fischer 1983, 1985, and Pike 1965). Nevertheless, we believe this question deserves more attention than it actually received and, for that reason, we try to provide an answer here. To be fair, however, we shall sketch the origin of the question. Discussing the problem of foreknowledge and freedom, Fischer says that the person who is God, but who would depend on human actions, would not be worthy of worship, meaning 
that "it is theologically implausible to suppose that any human agent is free so to act that the person who is actually God would not be God" (Fischer 1983, 79). Pike thinks that this is not in fact explained, on the following grounds. It seems that Fischer's reasoning depends on principle (P): "If it were within Jones's power at $\mathrm{t} 2$ so to act that Yahweh held a false belief, was not omniscient and thus was not God at $\mathrm{t} 1$, Yahweh would not be worthy of worship" (Pike 1984, 604). 'Yahweh' is used here as a name for God, and we will presently explain using the name 'Yahweh' for person $\mathrm{X}$ who can be God. This means that if Jones has (and he even does not have to exercise) the power to do otherwise than Yahweh believed, it would mean that Yahweh did not occupy the role of God because there is a possibility that Yahweh then held a false belief which should be impossible for essentially omniscient God. Pike then asks us to consider the following principle, $(\mathrm{Q})$ : "Yahweh would not be worthy of worship had He created (or even permitted) a universe in which no human action is freely performed" (Pike 1984, 605). This principle, together with the assumptions that Yahweh is God, that there will be human actions and that ' $t_{1}$ ' designates a time before performing any of these actions, imply that although God was omniscient at $t_{1}$, some human action has been or will be freely performed and that incompatibilist thesis is false. Of course, continues Pike, principle $Q$ is not self-evident and is not argued for. Pike thinks the same about Fischer's proposal mentioned at the beginning of the footnote. At last, Fischer argues that the acceptance of Q need not imply rejection of incompatibilism (Fischer 1985, 84-88).

The reasons for using both 'Yahweh' and 'God' in the debate are the following: Fischer diagnoses that Pike uses 'God' in two ways - sometimes as a rigid designator and sometimes as a 'role-indicator' and thus as a non-rigid designator. Rigid designators designate one and the same object/person in every possible world it exists, though different objects/persons can fulfil the same designated roles in different possible worlds. Therefore, non-rigid designators can designate different objects/persons in different possible worlds. So, the rigid designator 'Yahweh' designates one and the same person in every possible world it exists; in some world or worlds that person can be God, but on some interpretations, in other possible worlds Yahweh does not have to be God. Though exposing and discussing this slipping of usage (shift in the usage?) of the term 'God' (rigidly and non-rigidly) is important for parts of the foregoing discussion about God's foreknowledge and human freedom, it need not concern us for our purposes. We are interested in this paper whether whoever is God (a person having the divine attributes) would be worthy of worship had He created or even permitted the world where no human action is freely done. It is not important here whether there is one and the same person who is God in all possible worlds (which we think is the case) or different persons occupy the role of God in different possible worlds.

So, we would like to say a few words about something which is in fact a side-issue in this debate but seems interesting in itself. We would like to offer some reasons and to describe possible circumstances in which God could be worthy of worship even if He had created a world in which no action could be freely done. It will be evident that some contextual circumstances of certain situations or possible worlds allow us to say that God is worthy of worship even if He had created a world in which no action could be freely done.

It seems at first sight that it is plausible (and perhaps with no further argument needed) that God would not be worthy of worship had He created, or even permitted, the world where no action is freely done. Traditionally, one of the main reasons for which God is considered worthy of worship is that He created us possesing freedom of the will and freedom of action. So, if it were not the case that we posses freedom of the will and freedom of action it seems 
that we must conclude that the God who created such a world would not be worthy of worship. But we think that we can construct possible circumstances and see that God could be worthy of worship even if He had created a world in which no action is freely done if we look at the possible consequences in that situation.

Before addresing our question, let us be reminded of some commonplaces from the debate on free will, determinism and responsibility.

\section{Free will, determinism and responsibility}

Deterministic incompatibilism or hard determinism says that freedom and determinism are incompatible in the sense that if determinism is the case, then any action and the will are completely determined by factors outside the control of agents: by laws of nature and by previous or initial conditions which had existed before the agents came into existence. In such a world everything is determined by the laws of nature and the initial conditions and nobody can do otherwise than he in fact does. So, everything that happens, including what human beings (and other beings) think and do, can be explained by factors (laws of nature + initial conditions) on which 'agents' do not have any influence and by which they are fully determined.

The doctrine of no moral responsibility, which goes hand in hand with deterministic incompatibilism, ${ }^{6}$ says that if no (human) being can act freely in any sense, that is, if any (human) being is fully determined in some way that is completely out of the control of that (human) being, and no (human) being can refrain at any moment from what that (human) being is doing, then no (human) being is morally responsible for any of his or her actions. Of course, this doctrine is by no means accepted by everyone, but there are good arguments in favour of it, and therefore we can assume it for the sake of argument and say the following.

\section{Worthy of worship? Yes!}

It is possible that God holds the doctrine of no moral responsibility as described above. Moreover, if the doctrine is true, according to His omniscience, He then knows it. Another of God's essential attributes is His absolute benevolence or omnibenevolence. If this is so, then according to His absolute benevolence, He not only knows, but also applies the doctrine of no moral responsibility.

So, if God holds this doctrine, then, for any completely deterministic world, and for any world in which not a single action is freely done, and nobody can act otherwise than he in fact has done, nobody can be responsible for any of his or her deeds even in God's eyes. If God judges that nobody is responsible for his or her actions, then no one can be judged to be punished for what he or she has done. Nobody can be blamed for anything that he or she has done; not a single punishment would be deserved by human beings in that world, so the ultimate consequence would be that in such a world, nobody would go to hell.

\footnotetext{
${ }^{6}$ For the formulation of the arguments for incompatibilism of free will and determinism see, for example, van Inwagen (1983), and Lamb (1977), the latter also containing a formulation of the doctrine of no moral responsibility; for the doctrine see also further defenses and discussions in van Inwagen (1983, 183-186), Strawson (1994), Haji (2009, chapter four) and Waller (2011). For all the variety of issues pertaining the problem of free will, see Kane (1996).
} 
On the other hand, it is also true that nobody is praiseworthy for anything that he does. So there can be no merit for doing good deeds. There can be no merit for going to Heaven. But if God can even forgive sins (in the worlds where there are free actions and free will) and allow sinners to go to Heaven after forgiving them, then it is reasonable to suppose that, where there are no sins (in a completely deterministic world), and God does not even have to forgive, and, also due to His omnibenevolence, He can allow every (human) being to go to Heaven (if He holds the doctrine of no responsibility). Even when there are no merits for 'good' deeds, since there are in fact no good deeds or bad deeds and sins, since everything is completely determined by factors outside the control of agents, due to God's omnibenevolence, which includes God's grace, God can neglect that - namely, merit as a fact which would qualify someone to go to Heaven - and go in favour of every (human) being to provide a better (in fact, the best) solution.

Why do we say 'a better solution' here? Someone might object that if the world is completely determined and there are no sins and good deeds and no one is responsible for what has been done, then there will be no punishment but no merit and praise either; the result would be neutral or nothing: no one will go to hell, but no one will go to Heaven either; after death only death would remain; that would be the right, neutral solution between hell and Heaven. But eternal life in Heaven is surely better than death (think about death as eternal nothingness, which is in turn better than eternal suffering in hell). Since God is omnibenevolent, He can grant, according to His grace, a better outcome for human beings even if they do not deserve it by themselves when the case is that they also do not deserve any kind of punishment at all. He can go in favour of human beings.

It seems that such reasoning could beg the question of why God would create such a deterministic world in the first place? Two answers are possible, we think.

Assume that God's foreknowledge and human free action are incompatible. Then it is not at all possible for humans to perform free actions. No action can be performed freely (in any universe that can be created or in any possible world). Then, if God holds the doctrine of no moral responsibility, and according to His omnibenevolence, He can apply what is said above. It follows in some direct way.

Assume, alternatively, that God's foreknowledge and human free action are compatible. Then there is at least one possible universe that could be created in which humans perform actions freely and God foreknows what humans will do (freely). If this is so, then He can simulate, before actually creating, every world He can create in which human beings act freely. He can simulate all the histories of such worlds from their creation to their end and what agents would do freely in these worlds. If He sees that in every world there would be at least one human being such that he or she would freely do evil deeds, bearing responsibility for them, and that these deeds would be such that the doer of them would deserve punishment to go to Hell, then God can decline to create any such world which contains free will and free action. Instead, He can choose to create a completely deterministic world with the application of that which is said above about the doctrine of no moral responsibility and His omnibenevolence, because it guarantees a better overall outcome - namely, everyone would be allowed to go to Heaven. This is surely a better outcome than even the outcome in which, for example, only one human being would have to go to hell. Therefore, this outcome could be a justification for creating a completely deterministic world. Of course, God may have other reasons as well, even reasons which we cannot comprehend. 
One question will remain to which we have no answer. When He is creating, why does God not create these beings immediately as beings in Heaven? To this question we have no possible answer, but God may have a reason why not. However, perhaps this is not such an important matter for our purposes, because we only wanted to construct a possible case in which we could say that God is worthy of worship in spite of having created (or permitted) a world in which no (human) action could be freely performed. If matters were as in our example, regardless of (our knowledge of) why God created such a world, we claim that He would still be worthy of worship. We do not need to have an answer for everything that God does. Moreover, we cannot know the reasons for everything that God does because $\mathrm{He}$ is much more intelligent than we are, and $\mathrm{He}$ is a perfect being, while we are imperfect. We think that it is quite obvious that imperfect beings cannot understand everything that a perfect being thinks and does. Some things we can understand, but not everything.

God would be worthy of worship because, creating a completely deterministic world, in conjunction with holding the doctrine of no moral responsibility and His omnibenevolence, He would provide the best outcome for everyone. Everyone would be allowed to go to Heaven. This is a sufficent reason for worshipping God.

Of course, in a completely deterministic world it may be the case that nobody actually worships God in that world. But the question we discussed was not whether anyone actually worships God in such a universe, but whether He would be worthy of worship - as a matter of principle - even if no one in that universe actually worships Him.

Consider also the following possible world B:

In $\mathrm{B}$, every sentient creature lives the entire life in pleasure; every single moment is joyful and pleasant for each and every creature; it literally means that there is no single unpleasant moment in the life of each and every sentient creature in this world. Not the slightest harm is done and it never happens to anyone. There is no kind of physical and metaphysical harm, pain or evil done in B. But, everything that happens in this world is completely determined in the sense of hard determinism. The initial states plus the laws of nature of this world determine everything that happens, according to the God's plan and creation of this world. Each and every event, and so, each and every action, and even each and every thought and feeling (namely every mental state or process), are also thus predetermined. There are no kinds of undetermined or chancy events in B. There is no (kind of) freedom in this world. Nothing can be otherwise than what in fact is in this world B. We can also even add that, in this world, these creatures do not know this and cannot come to know this. They are not able (because it is also predetermined for them thus) to come to know that hard determinism is the case in their world and that they completely lack freedom.

One thing has to be added. These creatures do not have to be some low-level creatures regarding knowledge and variability of life for example. They can be of various degree of development if development is the right word. What we want to say is that it is possible that they would know (and enjoy in knowing, of course, ex hypothesi), for example, much more than we do and have a much wide variety of life practices. Of course, if God created that this happens, but surely it is not impossible for Him to do just this.

In our world, we often admire if someone arranges some very complex things to behave as planned in every detail in a predetermined way. We show great respect for engineers that project and build complex machines which behave as designed and planned. And we admire if someone contributes to happiness and pleasure of others (of course, in our world, not at 
the same time causing harm and displeasure for still others). So, why would not God be worthy of worship if He created a world like B despite the fact that there is no freedom in it? ${ }^{7}$

\section{Conclusion}

To sum up: there are two main reasons why we can say that even if in our world (or in some other possible world) human beings are created by God and do not have freedom of the will, God is still worthy of worship. One reason is that if God is worthy of worship, and we think that $\mathrm{He}$ is, on accounts given by Swinburne (which is in fact a summary and precise philosophical development of, let's say, traditional thinking) - because of possessing attributes of omniscience, omnipotence, eternality, incorruptibility, etc., these attributes stay the same whether or not human beings have freedom of the will; the other is that if God holds the doctrine that, under determinism, no one is responsible for what he or she did, (and we believe that we have shown that it is rational to hold that God holds that doctrine), and so God will allow, due to His omnibenevolence, that every human being goes to Heaven, that fact alone would be enough to consider God worthy of worship. In this case, of course, other God's attributes also stay the same so they add up to God's worthiness of worship.

The case of possible world B speaks for itself: human beings live in full happiness from the beginning of their existence and this happiness is uninterrupted. We think that this alone, again, would be enough to establish that God is worthy of worship.

So, it seems to us that we can construct certain cases in which no action is done freely and no one ever acts freely, but in which God would be worthy of worship nonetheless. Of course, this shows that there are possible worlds in which just the sole fact that human beings do not enjoy freedom of the will and the freedom of the action does not suffice to render God not to be worthy of worship. It is clear that worthiness for worship depends as well on other contextual circumstances and facts of the world in which human beings are created by God but lack freedom of the will and freedom of the action.

\section{Acknowledgements}

We would like to thank the anonymous reviewers for Pro-Fil for very helpful comments. Tvrtko Jolić is supported by the Croatian Science Foundation (Grant Number: HRZZ-UIP-2017-05-4308.

\section{References}

Dillon, R. (2018): Respect, in Zalta, E. (ed.) The Stanford Encyclopedia of

Philosophy [online], 2003-9-10, rev. 2018-2-18 [accessed 2021-11-5], available at:

< https://plato.stanford.edu/archives/sum2021/entries/respect/ > .

Fischer, J. M. (1983): Freedom and Foreknowledge, The Philosophical Review 92, 67-79, available at: < https://www.jstor.org/stable/2184522 >.

\footnotetext{
${ }^{7}$ Again, as above, in a completely deterministic world it may be the case that nobody actually worships God in that world. But the question we discussed was not whether anyone actually worships God in such a universe, but whether He would be worthy of worship - as a matter of principle - even if no one in that universe actually worships Him.
} 
Fischer, J. M. (1985): Ockhamism, The Philosophical Review 94, 81-100, available at: <https://www.jstor.org/stable/2184716>.

Fischer, J. M. (1994): The Metaphysics of Free Will, Blackwell.

Haji, I. (2009): Incompatibilism's Allure, Broadview Press.

Hasker, W. (1989): God, Time, and Knowledge, Cornell University Press.

Hoffman, J. - Rosenkrantz, G. (2002): The Divine Attributes, Blackwell.

Ginet, C. (1990): On Action, Cambridge University Press.

Goetz, S. (2008): Freedom, Teleology, and Evil, Continuum.

Huemer, M. (2021): Knowledge, Reality and Value, Samizdat.

Kane, R. (1996): The Significance of Free Will, Oxford University Press.

Kane, R. (ed.) (2002): The Oxford Handbook of Free Will. Oxford: Oxford University Press.

Kronen, J. - Reitan, E. (2011): God's Final Victory, Bloomsbury.

Lamb, J. (1977): On a Proof of Incompatibilism, The Philosophical Review 86, 20-35, available at: < https://www.jstor.org/stable/2184160 >.

McCord Adams, M. (1967): Is the Existence of God a Hard Fact?, The Philosophical Review 76, 492-503, available at: < https://www.jstor.org/stable/2183285 >.

O'Connor, T. (2000): Persons and Causes: The Metaphysics of Free Will, Oxford University Press.

Pike, N. (1965): Divine Omniscience and Voluntary Action, The Philosophical Review 74, 27-46, available at: < https://www.jstor.org/stable/2183529>.

Pike, N. (1984): Fischer on Freedom and Foreknowledge, The Philosophical Review 93, 599-614, available at: < https://www.jstor.org/stable/2184829>.

Plantinga, A. (1974): God, Freedom and Evil, Eerdmans.

Pruss, A. (2008): The Essential Divine-Perfection Objection to Free Will Defence, Religious Studies 44, 433-444, available at: <www.jstor.org/stable/27749976 >.

Schultze-Kraft, M. et al. (2016): The Point of no Return in Vetoing Self-Initiated Movements, PNAS, 113, 1080-1085, available at: < http:/pubmed.ncbi.nlm.nih.gov/26668390/ >.

Smith, Q. (1997): Ethical and Religious Thought in Analytic Philosophy of Language, Yale University Press.

Strawson, G. (1994): The Impossibility of Moral Responsibility, Philosophical Studies 75, 5-24, available at: < www.jstor.org/stable/4320507 >.

Swinburne, R. (1993): The Coherence of Theism, Clarendon Press. 
Waller, B. (2011): Against Moral Responsibility, MIT Press.

van Inwagen, P. (1983): An Essay on Free Will, Oxford University Press.

van Inwagen, P. (1989): When is the Will Free?, Philosophical Perspectives 3, 399-422, available at: < www.jstor.org/stable/2214255 >.

van Inwagen, P. (2006): The Problem of Evil, Clarendon Press.

Warfield, T. (1997): Divine Foreknowledge and Human Freedom Are Compatible, Noûs 31, 80-86, available at: < https://www.jstor.org/stable/2216201 >.

Zagzebski, L. (1991): The Dilemma of Freedom and Foreknowledge, Oxford University Press.

This work can be used in accordance with the Creative Commons BY-NC-ND 4.0 International license terms and conditions (https://creativecommons.org/licenses/by-nc-nd/4.0/legalcode). This does not apply to works or elements (such as images or photographs) that are used in the work under a contractual license or exception or limitation to relevant rights. 